\title{
Trophic State Evolution over 15 Years in a Tropical Reservoir with Low Nitrogen Concentrations and Cyanobacteria Predominance
}

\author{
Frederico Guilherme de Souza Beghelli • \\ Daniele Frascareli • Marcelo Luiz Martins Pompêo • \\ Viviane Moschini-Carlos
}

Received: 30 March 2015 / Accepted: 21 February 2016/Published online: 1 March 2016

(C) Springer International Publishing Switzerland 2016

\begin{abstract}
Anthropic eutrophication is one of the most widespread problems affecting water quality worldwide. This condition is caused by excessive nutrient inputs to aquatic systems, and one of the main consequences is accelerated phytoplankton growth. Eutrophication can lead to damage to human health, the environment, society, and the economy. One of the most serious consequences of eutrophication is the proliferation of cyanobacteria that can release toxins into the water. The aim of this research was to evaluate the trophic condition of a tropical reservoir over the course of time, using a database extending over 15 years to investigate relationships with environmental conditions, considering spatial heterogeneity and seasonality, as well as inter-relations between trophic state indicators. Data for chlorophyll-a, total phosphorus, and total nitrogen were collected from 2000 to 2014, and cyanobacteria abundance was determined from 2004 to 2014. The trophic state index was also calculated. The results
\end{abstract}

Electronic supplementary material The online version of this article (doi:10.1007/s11270-016-2795-1) contains supplementary material, which is available to authorized users.

F. G. de Souza Beghelli $(\bowtie) \cdot$ D. Frascareli •

V. Moschini-Carlos

Institute of Science and Technology of Sorocaba, São Paulo State University-UNESP, Avenida Três de Março 511, Alto da Boa

Vista, Sorocaba, SP 18087-180, Brazil

e-mail: fred_sb@hotmail.com

M. L. M. Pompêo

Institute of Biology - Department of Ecology, São Paulo

University-USP-IB, R. do Matão, Travessa 14, 321, Butantã,

São Paulo, SP 05508-090, Brazil demonstrated the existence of two distinct compartments in the reservoir: one lotic and the other lentic. No relationship was observed between chlorophyll-a and phosphorus. The results suggested that phytoplankton growth was mainly controlled by nitrogen concentrations. These conditions favored cyanobacteria predominance, resulting in increasing abundance of these potentially toxic bacteria over time. The model obtained indicated hypereutrophic conditions, with high phytoplankton biomass and cyanobacteria abundance during the next years likely to affect the uses of the water of the reservoir.

Keywords Water quality · Phytoplankton - Limnology · Cylindrospermopsis · Trophic state

\section{Introduction}

Water is an essential resource for humans and other organisms. It is fundamental for ecosystem maintenance and is a determining factor in the development of societies, since it is essential for most economic and social activities (Saurí 2013; UN 2014). Due to human population growth and associated development, this resource has suffered progressively more intensive pressure, resulting in a situation where demands for water may outstrip supply in the next decades (Saurí 2013), while water quality becomes increasingly worse (Bogardi et al. 2012).

Artificial dams are built in order to regulate water flow and store water for purposes such as public water supply and power generation (Tundisi 2008). Once a 
dam is built, the conditions of the water body and the surrounding land are modified. The aquatic ecosystem progressively changes from a lotic condition to a lentic state. This change in flow drastically alters the environment by generating conditions with physical, chemical, and biological gradients (Karmakar et al. 2011). These differ from the preceding conditions and are associated with greater accumulation of nutrients (Smittenberg et al. 2004; Pereira et al. 2013), higher sedimentation rates, and lower bottom oxygenation, which favor the eutrophication process (Heath and Plater 2010; Cunha 2013).

The eutrophication of aquatic environments can be understood as a group of ecosystem responses to increased inputs of nutrients, especially phosphorus and nitrogen. This process can occur naturally in lakes, leading to gradual changes. However, in the presence of anthropic interference, with inputs of nutrients derived from agriculture, cattle, or sewage discharge, artificial eutrophication occurs, causing changes that are much faster, compared to natural eutrophication (Zan et al. 2012).

The Carlson trophic state index (Carlson 1977), as well as others based on nutrient and chlorophyll relationships, is based on the limiting factor concept. Generally, the limiting factor will be the one that is least available in the environment, when other factors are not limiting for growth or reproduction. In the case of phytoplankton, which are usually the main agents responsible for primary production in continental aquatic ecosystems, the most common limiting factors are nitrogen or phosphorus. According to this concept, the availability of the limiting factor will modulate the response by the organism. Considering the trophic state of an aquatic system, the phosphorus or nitrogen concentrations will generally determine the chlorophyll concentration. This is the basic hypothesis employed in trophic state indexes (Tundisi and Matsumura Tundisi 2008).

The undesirable effects of eutrophication include alterations in aquatic communities (Beghelli et al. 2012; Freedman et al. 2012; Soares et al. 2013), reduced oxygen levels (Valente et al. 1997), algal blooms (Liu et al. 2011), unpleasant odors, fish mortality, and proliferation of cyanobacteria, many of which are potential toxin producers (Pretty et al. 2003).

Economic impacts can also result from eutrophication processes. According to Pretty et al. (2003), the cost associated with eutrophication in England and Wales is around 121-184 million dollars per year. In Brazil, studies of eutrophication are scarce. Sirigate et al. (2005) reported rising costs of water treatment due to increased microalgae densities caused by eutrophication. The costs of water treatment increased up to twofold, although actual values were not presented.

According to the financial accounts published in the Official Gazette of the State of São Paulo, Brazil (São Paulo 2015), the company responsible for water treatment spent R \$ 4.08 million (about US\$ 1.30 million, considering the currency exchange rate in the month when the purchase was made) in the acquisition and transport of 400 tons of copper sulfate, an algicide.

Considering the significance of eutrophication, there is a need for simple indexes that are based on a few variables that can be easily understood by non-specialists. The Carlson trophic state index (Carlson 1977) satisfies this criterion. However, despite the widespread use of this index, it is not suitable for tropical or subtropical ecosystems (Petrucio et al. 2006; Silvino and Barbosa 2015) where phytoplankton communities and climate dynamics are distinct from those in the temperate regions on which Carlson's work was based (Cunha et al. 2013).

Considering this, the index was later adapted for tropical and subtropical environments by Salas and Martino (1991), following evaluation of total phosphorus concentrations in 27 tropical and subtropical lakes and reservoirs. Lamparelli (2004) proposed an adaptation of the Carlson index for the State of São Paulo, which has been extensively used by the State's Environmental Protection Agency (CETESB), as well as other Brazilian environmental agencies, as an official Brazilian eutrophication index. Recently, Cunha et al. (2013) published an update of the Lamparelli index for reservoirs. The main differences between the Cunha index and the Lamparelli index are the adjusted ranges considered for each trophic status, with more restrictive categories and a distinct database that considers 18 reservoirs and data from 1996 to 2000, with greater data availability, including Secchi disk measurements.

The present work concerns the Itupararanga reservoir, which is located in an urbanized region of São Paulo State (Fig. 1). Here, the original vegetation is predominantly semi-deciduous forest and the climate is type Cwa, according to the Köppen classification, with distinct wet and dry seasons. The wet season is between October and March, when more than $80 \%$ of the total rainfall occurs, and the dry season is between 
April and September. Annual average rainfall at the reservoir is around $1493 \mathrm{~mm}$. About $68 \%$ of the original vegetation of the watershed has been removed or replaced (Beu et al. 2011), and the main land use is now agricultural (Pedrazzi et al. 2013).

The population of the cities around the Itupararanga drainage basin grew from 442 to 615 thousand people between 1996 and 2010, which has led to increased pressure on water resources. The water from the Itupararanga reservoir is used for many purposes, including power generation by the CBA company, public water supply $\left(2.2 \mathrm{~m}^{3} / \mathrm{s}\right.$ to 850,000 people $)$ in the Sorocaba region (Sorocaba is the main city in the region and its population of about 586,625 people consumes $\left.1.93 \mathrm{~m}^{3} / \mathrm{s}\right)$, intensive irrigation $\left(1.5 \mathrm{~m}^{3} / \mathrm{s}\right)$, fisheries, and the regulation of water flow.

The main sources of pollution in the Itupararanga reservoir are sewage discharges and inputs of agrochemicals in runoff due to inappropriate land management along the margins of the reservoir (Taniwaki et al. 2013) and along tributary rivers. Poor sewage treatment is an aggravating factor. Conditions are especially poor in the municipalities of Ibiúna and Vargem Grande Paulista, through which tributary rivers pass (Salles et al. 2008) and where there are low levels of sewage treatment. Residual domestic sewage loads calculated by CETESB for 2014 were 724 and $2585 \mathrm{~kg}$ BOD/ day in Ibiúna and Vargem Grande Paulista, respectively, discharged into the Vargem Grande stream, the main affluent of the Sorocaba Mirim and Una rivers (CETESB 2015).

\subsection{Hypothesis and Objectives}

This work is based on the hypothesis that the Itupararanga reservoir has followed an increasing trend of eutrophication because of population growth without adequate environmental policies to avoid deterioration of water quality. In this scenario, the phytoplankton response is growth over time accompanied by a shift from a community dominated by Chlorophyceae to a community where cyanobacteria prevail. In such a situation, where phosphorus is abundant but nitrogen is not, the use of trophic state indexes based on a direct relationship between phytoplankton growth and total phosphorus may be unable to describe the trophic status of the environment.

Considering the importance of understanding the eutrophication process and monitoring the changes over time, as an essential part of water quality management, the purpose of this work is to evaluate the evolution of the trophic state in a tropical reservoir over a period of 15 years. The results should contribute to understanding the eutrophication process and its consequences in tropical environments.

\section{Materials and Methods}

A database of cyanobacteria numbers and the concentrations of chlorophyll-a (Chl), total phosphorus (TP), ammonia, nitrite, nitrate, and total Kjeldahl nitrogen was compiled from the CETESB annual reports for the

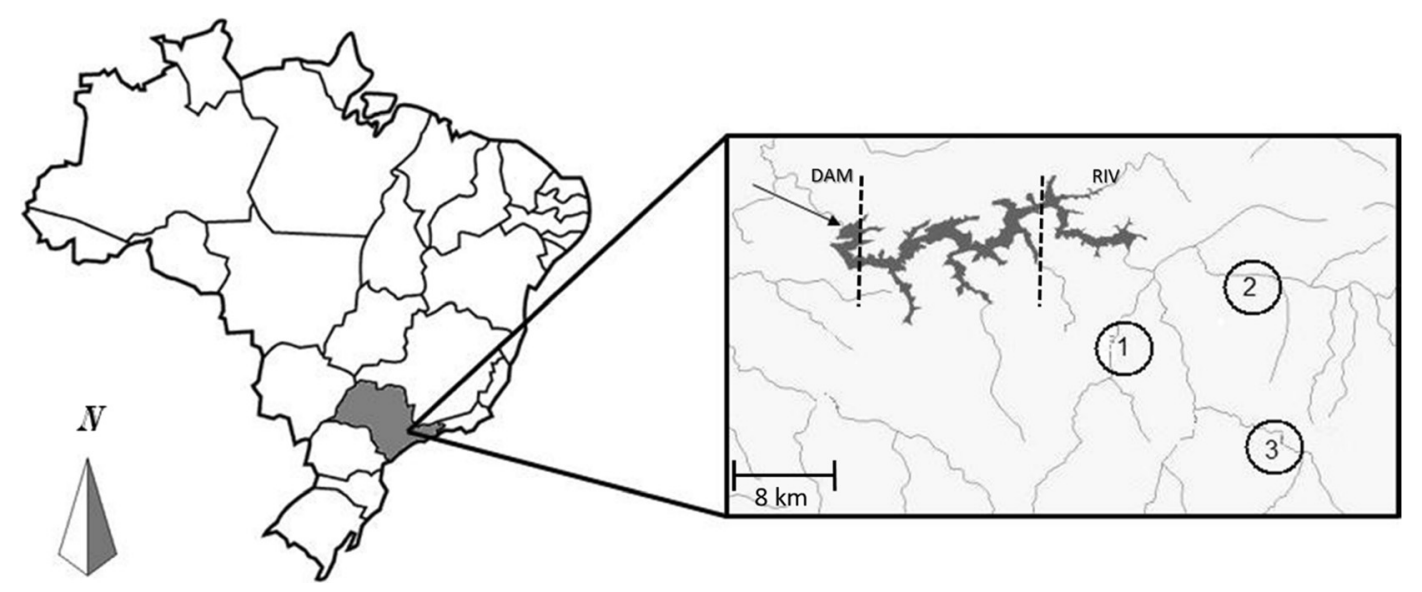

Fig. 1 Location of the Itupararanga reservoir in São Paulo State. The numbers indicate the main feeder rivers: (1) Una River, (2) Sorocaba Mirim River, and (3) Sorocabuçu River. The arrow indicates the dam position. Dashed lines separate the compartments considered in this study: the dam region (DAM) and the riverine zone (RIV) 
period 2000-2014 (CETESB 2001; 2002; 2003; 2004; 2005; 2006; 2007; 2008; 2009; 2010; 2011; 2012; 2013; 2014; 2015). Information concerning the numbers of cyanobacteria was available after 2004.

For each year, the CETESB data were obtained for 3 months during the dry season (May, July, and September) and 3 months during the wet season (November, January, and March). The annual reports provided data for the dam and riverine zones previously described by Cunha and Calijuri (2011a). Transitional and lacustrine zones were not considered, in order to maintain comparable data suitable for statistical analyses. CETESB did not provide data for the central body of the reservoir.

Total nitrogen was calculated by summing the concentrations of $\mathrm{TKN}, \mathrm{NO}_{3}{ }^{-}$, and $\mathrm{NO}_{2}{ }^{-}$. TN:TP ratios were calculated by two methods: one considering concentrations (Kolzau et al. 2014) and the other considering molar ratios (Tundisi and Matsumura-Tundisi 2008). The molar ratio was obtained by multiplying the TP values by 0.452233 , considering the atomic masses.

Trophic state indexes were calculated according to the method proposed by Cunha et al. (2013). The Cunha index was preferred to the Lamparelli (2004) index, for two reasons: the use of data that were more recent and the fact that the later index has been published in a scientific journal with an international audience, while the earlier index was published as a thesis. We believe that use of an index published in a scientific journal should facilitate understanding and comparison of the data by a wider audience.

The index values were calculated from the TP and Chl concentrations, as shown in Eqs. 1 and 2, and the final index, $\mathrm{TSI}_{\mathrm{ts}}$, was calculated as the arithmetic mean of the two individual indexes.

$\mathrm{TSI}_{\mathrm{TP}}=10 \times\left\lfloor 6-\left(\frac{-0.27637 \ln \mathrm{TP}+1.329766}{\ln 2}\right)\right\rfloor(1)$

$\mathrm{TSI}_{\mathrm{Chl}}=10 \times\left\lfloor 6^{-}\left(\frac{-0.2512 \ln \mathrm{Chl}+0.842257}{\ln 2}\right)\right\rfloor$

A final matrix was compiled with all the data, including year, region of the reservoir, and season as criteria for statistical analysis of variance (ANOVA), using a block design to test hypotheses about spatial heterogeneity and seasonality (using $95 \%$ confidence intervals).
In the first ANOVA $(p<0.05)$, the relationships between chlorophyll-a or cyanobacteria and total nitrogen or total phosphorus concentrations were tested, considering spatial or seasonal variability as required.

The classical linear models (simple linear regressions and correlations) are based on ordinary least squares (OLS) regression and assume normal distributions of the variables and the residuals, while generalized linear models (GLM) can handle a wider range of situations because they can accommodate non-stable variance and alternative exponential residual distributions. In GLMs, parameter estimation and model fitting are achieved by maximum likelihood procedures, instead of OLS fitting (Logan 2010).

Model selection was based on Akaike information criteria (AIC), employing the maximum likelihood approach. AIC values represent the information lost when a given model is used to describe the full reality. Consequently, a general conclusion is that when two or more models are compared, the one with the lowest AIC value will be considered as the best. Calculations of evidence ratios are based on $\triangle \mathrm{AIC}$ values (the difference between any model and the model with the lowest AIC) and provide useful information for model evaluation. The evidence ratio provides an indication of the number of times a given model is better than another (Burnham et al. 2011).

Generalized linear models were used to generate predictive models of the geometric means of chlorophyll-a in response to total phosphorus and total nitrogen, considering the influence of seasonality or spatial heterogeneity, in accordance with the ANOVA results. A gamma distribution was preferred to Gaussian, because negative values were not appropriate for the data considered in this study (Zurr et al. 2009).

The GLM approach was also used to describe the temporal trends of the geometric means for chlorophyll-a and cyanobacteria. Models were tested considering the link functions: identity, reciprocal (inverse), and log. Only models that conformed to the premise of non-zero slope were considered. The slope $p$ values were used to test for the presence $(p<0.05)$ or absence $(p>0.05)$ of a relation between the predictor and response variables, considering a confidence interval of $95 \%$.

A reduced model, considering only the intercept, was generated for comparison with the predictor-response variable models. Evidence ratios were calculated, comparing each model with the reduced model $\left(w_{j} / w_{0}\right)$ in 
order to obtain information about how many times each full model was stronger than the reduced model. Additional evidence ratios were calculated between the models with the lowest AIC and the other models $\left(w_{l} /\right.$ $w_{j}$ ). The information obtained enabled evaluation of the ability of the models to explain the observed variability, and whether the difference between the model with the lowest AIC and any other model was substantial, or if it would be plausible to select a simpler model. Evidence ratios higher than two were considered significant.

In situations where $w_{l} / w_{j}<2$, the model selection preference was the simplest regression, following the sequence: identity-log-reciprocal. Finally, the models for temporal trends were extrapolated to 2015, 2020, and 2025 in order to predict average values in future years and to test predictability. Similarly, the models that simulated relationships between nutrients and chlorophyll-a were tested by simulating conditions in which nutrient concentrations were the minima and the maxima recorded, as well as two and three times the maxima. The models were only considered satisfactory if they could predict trends up to at least 2020, or concentrations that were twice the highest values recorded. Models that predicted negative values were not considered. Statistical comparisons employed the Spearman correlations and $t$ test $p$ values. Statistical analyses and modeling were performed using RStudio 0.99.489 software (R Core Team 2015).

\section{Results}

\subsection{Spatial and Temporal Heterogeneity}

Higher means for chlorophyll-a concentrations were recorded in the riverine zone (mean $=11.09 \mu \mathrm{g} / \mathrm{L}$, $\mathrm{SD}=7.60, p=0.0009$ ), compared to the dam zone $($ mean $=7.14 \mu \mathrm{g} / \mathrm{L}, \mathrm{SD}=6.64)$. No spatial heterogeneity was observed for the other variables. Seasonality was only observed for total phosphorus concentrations $(p=0.0004)$. Table 1 presents the mean values and standard deviations, considering spatial heterogeneity and seasonality, together with the ANOVA results.

\subsection{Trophic State Index, Nutrient, and Chlorophyll-a Relationships}

Using the trophic state classification described by Cunha et al. (2013), the values for the dam and riverine zones revealed the occurrence of an eutrophication process over the course of the years. There was a high frequency of disagreement (60-93\%) between the indexes based on chlorophyll-a and phosphorus. Higher phosphorus index values were observed between 2001 and 2006, especially for the dam zone and during the dry season. Chlorophyll index values were higher after 2008 (Fig. 2).

No significant correlation was observed between the concentrations of total phosphorus and chlorophyll-a ( $p$ slope $>0.05$ ). However, chlorophyll-a clearly varied as a function of the total nitrogen concentration ( $p$ slope $<0.05$ ). The relationships between chlorophyll-a and the nutrients are shown in Fig. 3.

The relationships between chlorophyll and total nitrogen could be described by Eqs. 3 (riverine zone) and 4 (dam zone), considering chlorophyll and total nitrogen concentrations in units of microgram per liter and milligram per liter, respectively. Log link was selected for both the riverine and dam zones, as it resulted in lower AIC values and evidence ratios that indicated that $\log$ functions were more suitable than other links $\left(w_{l} / w_{j}>2\right)$. The gamma log-linear model was 219 and 2301 times stronger than the reduced model, considering data for the riverine and dam zones, respectively. Data for the dam zone could not be fitted by a regression with identity link, considering a gamma distribution (Table 2).

$\mathrm{Chl}_{\mathrm{RIV}}=e^{(3.50 \mathrm{TN}-0.58)}$

$\mathrm{Chl}_{\mathrm{DAM}}=e^{(4.08 \mathrm{TN}-1.35)}$

The values for the TN:TP concentration ratio varied in the ranges 13.6-118.2 during the dry season and 18.27-121.03 during the wet season. For TN:TP (molar) the ratio varied in the ranges 29.98-261.46 during the dry season and 40.40-267.63 during the wet season. The greatest increase occurred between 2008 and 2013 (Fig. 4).

\subsection{Annual Trends}

Although the TP and TN concentrations showed no obvious temporal trends ( $p$ slope $>0.05$; data not shown), the chlorophyll-a concentrations increased over time ( $p$ slope $<0.05$ ). This relationship could be described by gamma log-linear functions for the riverine 
Table 1 Means and standard deviations (SD) for total nitrogen (TN) and total phosphorus (TP) concentrations (mg/L), chlorophyll-a (Chl) concentrations $(\mu \mathrm{g} / \mathrm{L})$, numbers of cyanobacteria (Cya) (cells $/ \mathrm{mL}$ ), and TN:TP ratios based on concentrations $\left(\mathrm{TN}: \mathrm{TP}_{\text {conc }}\right)$ and molar ratios $\left(\mathrm{TN}: \mathrm{TP}_{\mathrm{atm}}\right)$, considering spatial division into riverine (RIV) and dam (DAM) zones and seasonality (wet and dry seasons). ANOVA results ( $p$ values) and sample sizes $(n)$ are also provided

\begin{tabular}{|c|c|c|c|c|c|c|c|}
\hline & & $\mathrm{TN}$ & $\mathrm{TP}$ & Chl & Cya & $\mathrm{TN}: \mathrm{TP}_{\text {conc }}$ & $\mathrm{TN}: \mathrm{TP}_{\mathrm{atm}}$ \\
\hline \multirow[t]{2}{*}{ RIV } & MEAN & 0.84 & 0.03 & 11.09 & 74,148 & 43.30 & 95.76 \\
\hline & $\mathrm{SD}$ & 0.29 & 0.03 & 7.86 & 76,231 & 36.85 & 81.48 \\
\hline \multirow[t]{2}{*}{ DAM } & MEAN & 0.77 & 0.03 & 7.14 & 87,073 & 47.76 & 105.61 \\
\hline & $\mathrm{SD}$ & 0.27 & 0.02 & 6.64 & 106,840 & 39.55 & 87.45 \\
\hline \multirow[t]{2}{*}{ WET } & MEAN & 0.79 & 0.02 & 9.92 & 86,386 & 52.96 & 117.11 \\
\hline & $\mathrm{SD}$ & 0.28 & 0.02 & 8.34 & 99,146 & 40.91 & 90.46 \\
\hline \multirow[t]{2}{*}{ DRY } & MEAN & 0.84 & 0.04 & 9.19 & 75,063 & 40.68 & 89.95 \\
\hline & $\mathrm{SD}$ & 0.28 & 0.03 & 7.01 & 86,694 & 35.41 & 78.30 \\
\hline \multirow[t]{2}{*}{$p$ values } & SPATIAL & 0.0980 & 0.1219 & 0.0009 & 0.4601 & 0.43800 & 0.43800 \\
\hline & SEASONALITY & 0.1117 & 0.0004 & 0.8689 & 0.5176 & 0.08629 & 0.08627 \\
\hline$n$ & - & 180 & 178 & 156 & 114 & 178 & 178 \\
\hline
\end{tabular}

and dam regions. For the riverine zone data, the model with log link was 2893 times stronger than the reduced model. Considering data for the dam region, log link resulted in the model with the lowest AIC, which was 2697 times stronger than the reduced model. These relationships are described in Eqs. 5 and 6 for the riverine and dam zones, respectively, where $y$ is the year.

The cyanobacteria densities also showed increasing trends that could be described by log-linear functions. The model selected was 51 times stronger than the
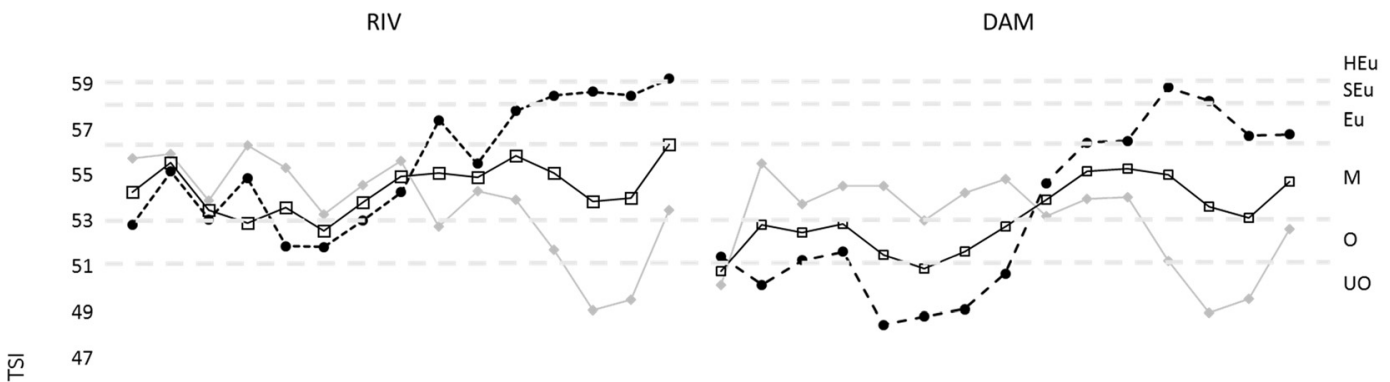

$\vdash$

WET
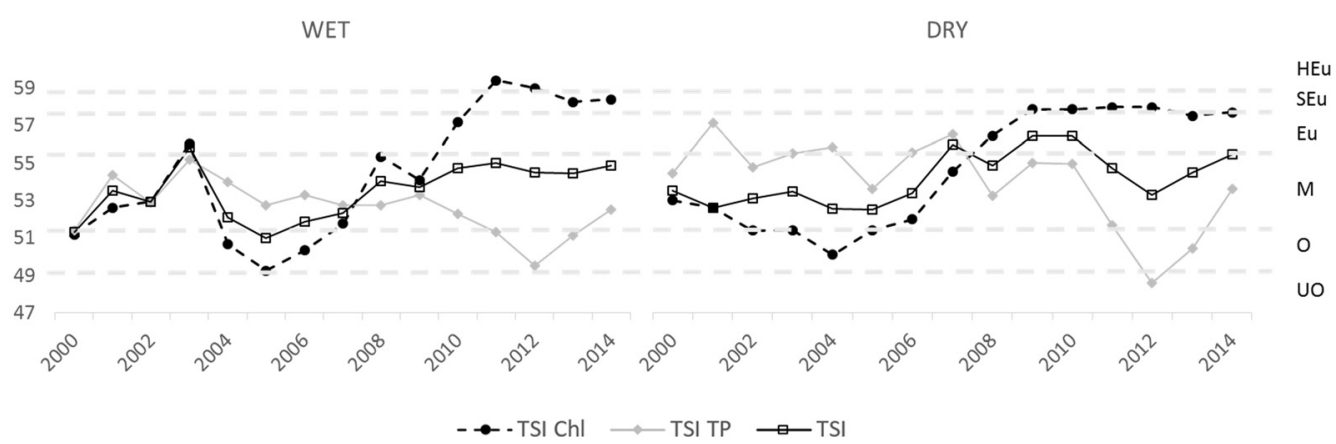

Fig. 2 Trophic state indexes calculated for the Itupararanga reservoir using the concentrations of chlorophyll-a (TSI Chl) and total phosphorus (TSI TP) and the average index (TSI), determined according to Cunha et al. (2013). The dam and riverine zones were considered separately, as were the wet and dry seasons. The horizontal lines in the charts indicate the ranges considered for each trophic state: ultraoligotrophic (UO), oligotrophic (O), mesotrophic (M), eutrophic (Eu), supereutrophic (SEu), and hypereutrophic $(\mathrm{HEu})$ 


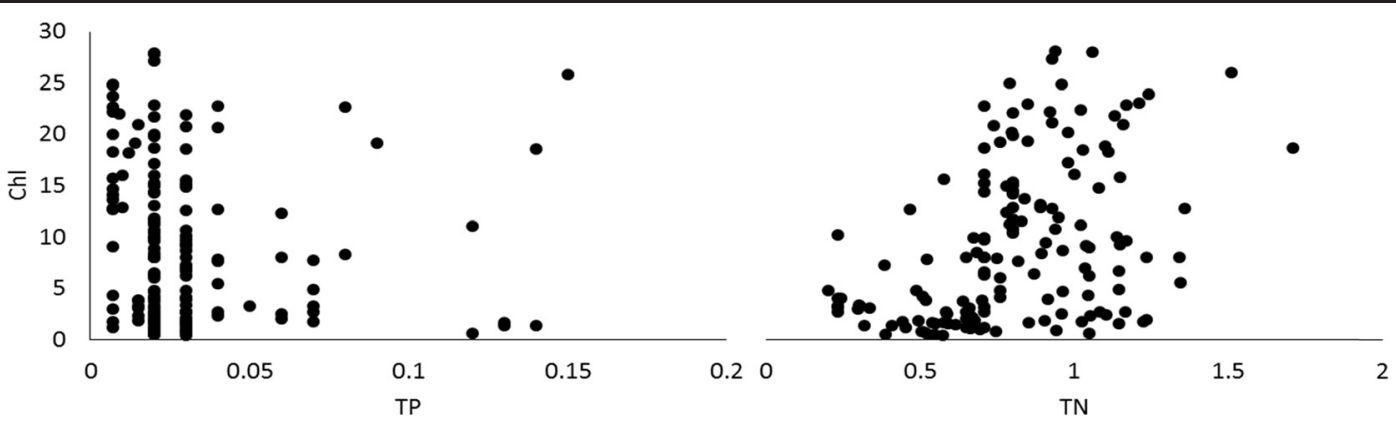

Fig. 3 Relationships between chlorophyll-a (Chl, $\mu \mathrm{g} / \mathrm{L})$ and total phosphorus (TP, mg/L), and between Chl and total nitrogen (TN, mg/L)

reduced model. A model with identity link could not be fitted. The GLM results are provided in Table 3 and Figs. 5 and 6. Eq. 7 describes the Cya-year relationship. The equations consider $\mathrm{Chl}$ in units of microgram per liter and Cya in units of cells/microliter.

$\mathrm{Chl}_{\mathrm{RIV}}=e^{(0.126 y-250.99)}$

$\mathrm{Chl}_{\mathrm{DAM}}=e^{(0.175 y-350.26)}$

$\mathrm{Cya}=e^{(0.34 y-679.12)}$

\section{Discussion}

\subsection{Spatial and Temporal Heterogeneity}

In a previous study, Cunha and Calijuri (2011a) proposed the division of the Itupararanga reservoir into four compartments, based on multivariable analysis. Although only the riverine and dam regions could be analyzed in the present work, the results corroborated the distinction between them. It is important to note that in the present work, only chlorophyll-a showed distinct differences, with higher values for the riverine zone, while the nutrients concentrations showed no clear differences between the zones. Cunha and Calijuri (2011a) attributed higher chlorophyll-a concentrations observed in the riverine zone to inputs of nutrients and transport of phytoplankton from tributary rivers. Similarly, in recent work that considered land use around the reservoir, Frascareli et al. (2015) concluded that the main source of phosphorus to the reservoir was its tributaries, while nitrogen inputs were related to agricultural activities.
Considering the absence of spatial heterogeneity for nutrients observed in our data, we believe that the entry of chlorophyll from the rivers is the best explanation for the high values in the riverine zone. Considering that chlorophyll is the response variable in the Carlson type trophic state indexes, we recommend that spatial heterogeneity should be considered when analyzing the trophic conditions of the Itupararanga reservoir, instead of using mean values.

As a rule, tropical reservoirs are characterized by seasonality in nutrient loadings, due to processes such as leaching, transport, and dilution rates. Seasonality has been also reported in relation to chlorophyll concentrations, which respond to nutrient levels and insolation (Malheiros et al. 2012; Buzelli and Cunha-Santino 2013; Chaves et al. 2013). Beghelli et al. (2014) previously documented the seasonality of other variables related to the trophic state of the Itupararanga reservoir in a 1-year study. Seasonal trends of chlorophyll, phosphorus, and nitrogen were recently reported by Frascareli et al. (2015).

Despite these results, in the present study with a longer data record, only phosphorus exhibited seasonality. This indicates that although the reservoir can present seasonality for chlorophyll and nitrogen in specific years, over longer periods, there was no significant seasonality of these variables. The pattern observed for TP concentrations evidenced an influence of allochthonous sources (Jordan et al. 2012).

The trophic state index values showed that there was a progressive degradation of water quality over time, especially when the index for chlorophyll is considered separately. In contrast, the index for phosphorus presented a decreasing trend during the 2009-2010 period, and an increasing trend in the last 3 years. A short period of decreasing trophic state index values was observed for the lentic compartment during 2003-2005. 
4.2 Relationships Among Trophic State Index, Nutrient Limitation, and Chlorophyll-a

Considering the evolution of the trophic state index for the Itupararanga reservoir and the high frequency of disagreement between the indexes for chlorophyll-a and total phosphorus, it is clear that any index that considers a direct relationship between these variables would have difficulty in describing environments similar to the Itupararanga reservoir, which could lead to misinterpretations.

Figure 2 clearly shows that the mean trophic state indexes are unable to satisfactorily represent the actual conditions in the reservoir. The mean indexes revealed only small changes in status and masked the eutrophication trend evidenced by the index based on chlorophyll. Carlson (1977) highlighted that in some cases, when the indexes for TP and Chl disagree, the results should be interpreted with considerable caution. When this type of index is employed, it is strongly recommended that the relationship between $\mathrm{Chl}$ and TP should be confirmed in order to ensure a realistic interpretation.

The disagreement between the trophic state indexes indicated that phytoplankton proliferation must have been limited by other environmental factors, such as nitrogen, illumination, or biological interactions (Cunha et al. 2013). Similar results were reported by Rangel et al. (2012), who detected a weak relationship between phosphorus concentrations and chlorophyll-a, especially in a eutrophic reservoir dominated by cyanobacteria, as well as by Huszar et al. (2006) in a comprehensive study using data for 192 lakes in tropical and subtropical regions. Neither of these studies offered a conclusive explanation of the findings, although possible explanatory factors included zooplankton predation, other nutrients, light limitation, and nitrogen limitation or co-limitation.

In an analysis of 21 reservoirs in the central region of Brazil, Carneiro et al. (2014) considered local (nutrients), morphological, and landscape factors, concluding that the best predictors of phytoplankton biomass were total phosphorus and depth. Despite methodological divergences among studies, it is clear that there is still no general consensus in explaining phytoplankton limitation, especially in tropical ecosystems, and that trophic state indexes must be adapted for application in unusual or unpredicted situations (such as the absence of correlation between TP and Chl). 
Fig. 4 Geometric mean TN:TP ratios for the Itupararanga reservoir in the wet and dry seasons during the period 2000 2014
DRY

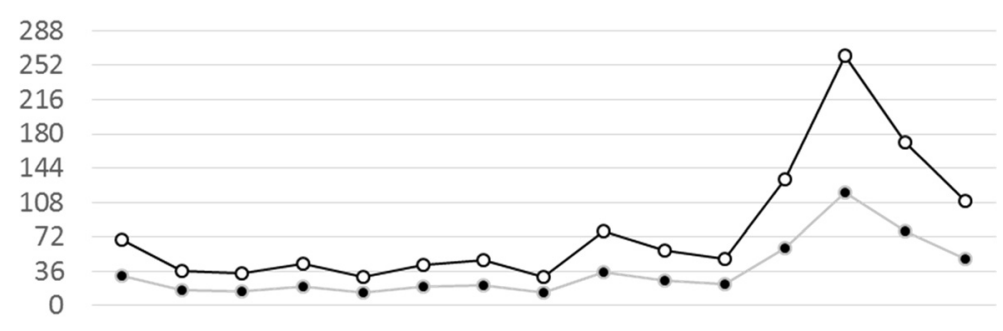

WET

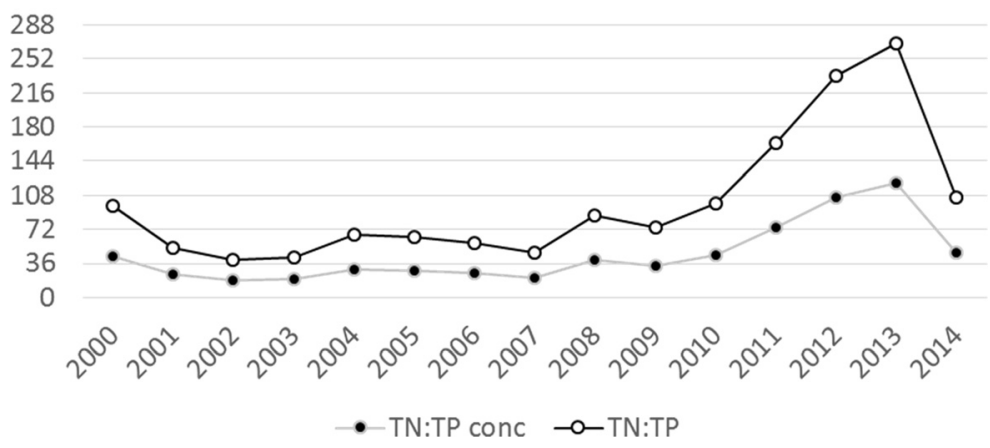

The TN:TP ratio values used to indicate limiting nutrients vary. A molar ratio of 16:1 was originally proposed (Tundisi and Matsumura Tundisi 2008). More recently, Kolzau et al. (2014) suggested that TN:TP concentration ratios below 18.5 might be indicative of nitrogen limitation. The criterion of $20<\mathrm{TN}$ : TP $<46$ for co-regulation, established by Dzialowski et al. (2005), was adopted by Cunha and Calijuri (2011a) and explained $40 \%$ of the results obtained for the Itupararanga reservoir.

Huszar et al. (2006) also studied limiting nutrients, reporting a total nitrogen mean concentration of $0.925 \mathrm{mg} / \mathrm{L}$ and a log-linear relationship between phosphorus and chlorophyll-a. In the present case, nitrogen only exceeded $0.925 \mathrm{mg} / \mathrm{L}$ in 2012 and 2015, with an overall mean of $0.805 \mathrm{mg} / \mathrm{L}$. It can be concluded from this that the Itupararanga reservoir presents low nitrogen values, in comparison with tropical and subtropical lakes limited by phosphorus. Broadly, the present data reveal limitation by nitrogen and co-limitation by phosphorus and nitrogen until 2010, phosphorus limitation in the last 5 years, and a tendency to return to nitrogen limitation after 2012.

These findings are in accordance with the relationships among Chl, Cya, and TN revealed in this study. Nitrogen limitation of the phytoplankton in the Itupararanga reservoir points to the need to use nitrogen concentrations for monitoring the trophic state of this and other similar reservoirs. Equations 3 and 4 could be used for this purpose for riverine and dam zones.

Several important changes can be seen from the data shown in Figs. 2 and 3. In the dam region, the trophic state determined using chlorophyll increased from 2008, reaching a peak in 2012, with a subsequent decrease (Fig. 2). Rosa et al. (2015) also reported a substantial change in the trophic state of the Itupararanga reservoir between 2007 and 2008, supporting the present findings and indicative of changes in terms of the limiting nutrient.

Greater disparity between the two indexes was observed after 2010, associated with a change in the state of the system and chlorophyll-a concentrations of the new community that exceeded the eutrophic limit (Carpenter 2003).

\subsection{Annual Trends}

The chlorophyll-a concentrations showed an increasing trend over time, and extrapolation of the data suggested that in 2025, concentrations of around 87.68 and $61.25 \mu \mathrm{g} / \mathrm{L}$ could be reached in the riverine and dam zones of the Itupararanga reservoir, respectively. This, together with alterations in nitrogen concentrations, would have a significant impact on the Chl-TN 


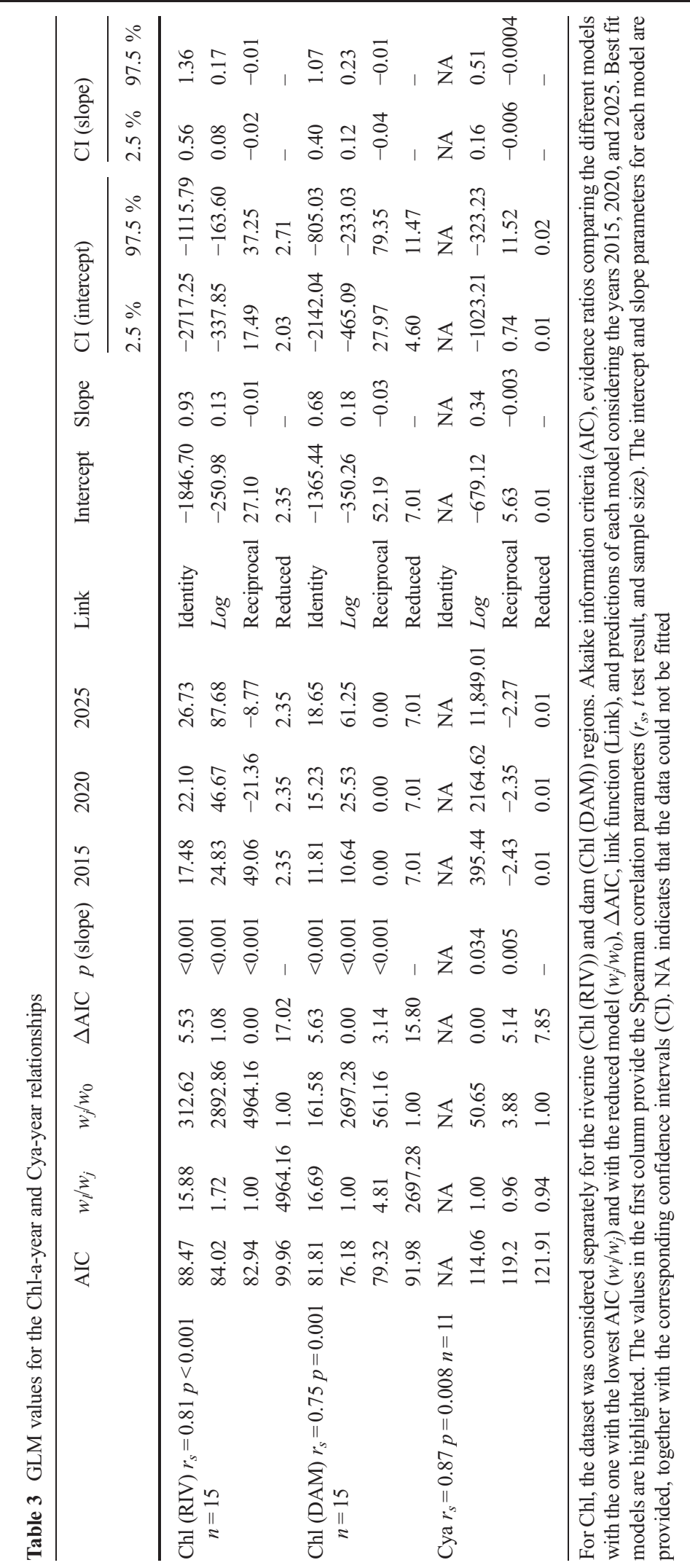




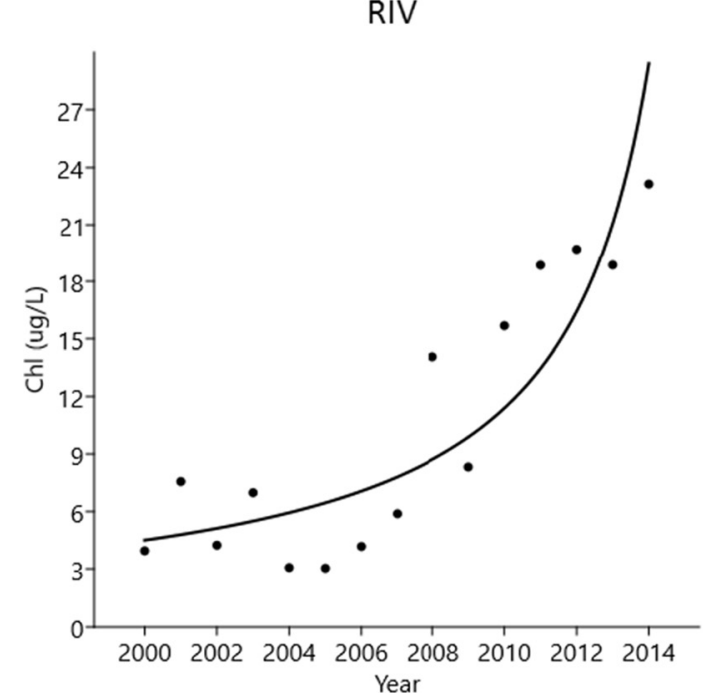

Fig. 5 Increasing chlorophyll-a (Chl) concentrations (geometric means per year) in the Itupararanga reservoir (São Paulo State,

relationship. Other influencing factors that were not directly considered here include land uses (Katsiapi et al. 2012), trophic interactions (Torres et al. 2016), light limitation (Loiselle et al. 2007), and global warming (Ye et al. 2011).

According to Brazilian legislation (CONAMA 2012), the Chl limit for continental class II water bodies is $30 \mu \mathrm{g} / \mathrm{L}$. Waters from sources within this class can be used for human ingestion (after conventional treatment), protection of aquatic life, swimming, irrigation of

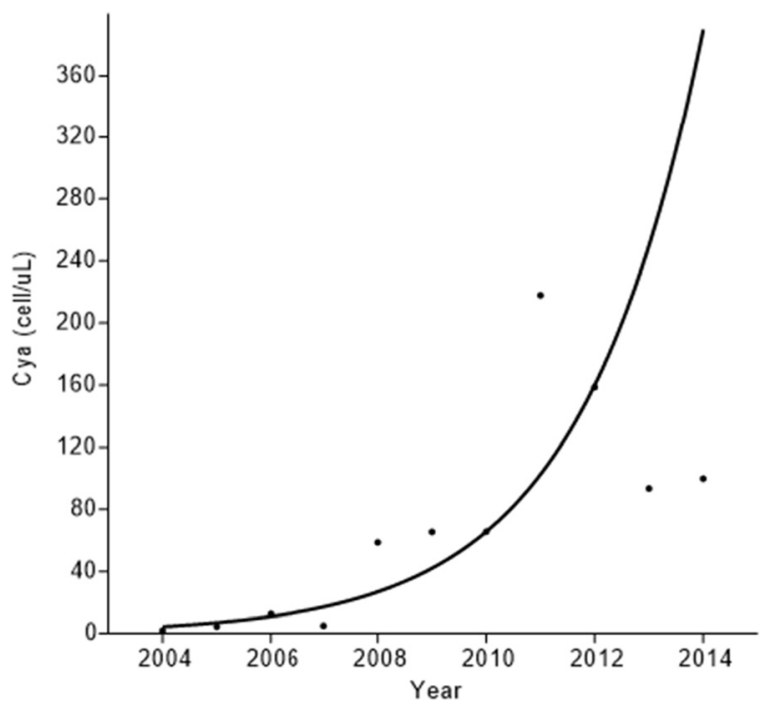

Fig. 6 Temporal evolution of the number of cyanobacteria cells per microliter (geometric means per year) in the Itupararanga reservoir
DAM

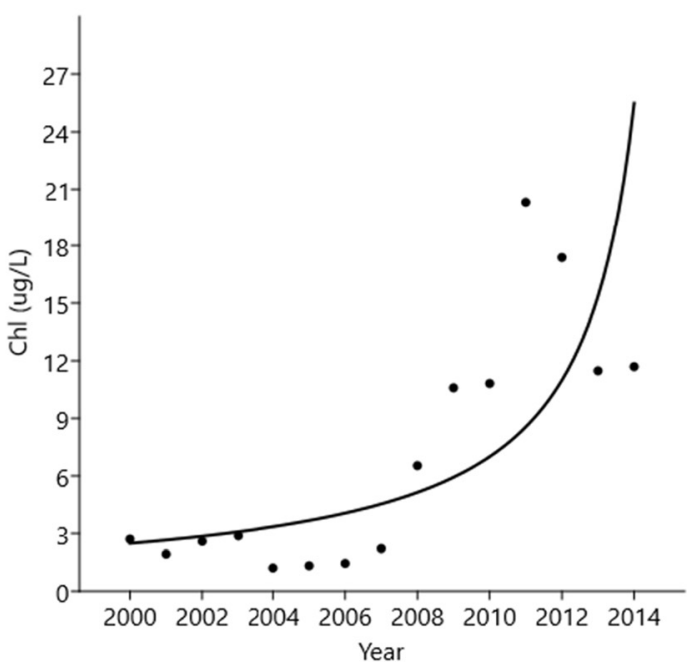

Brazil), considering the riverine (RIV) and dam (DAM) zones separately

greenery, aquaculture, and fishing. Since the limit of $30 \mu \mathrm{g} / \mathrm{L}$ was exceeded, Itupararanga water should not be used for swimming or irrigation of greenery, which are common activities at the reservoir. Furthermore, advanced water treatment may be necessary in the next years.

Alteration of the composition of the phytoplankton community could be a key factor for understanding the eutrophication process. Increases in the proportion of cyanobacteria in the phytoplankton community were observed in 2011 (Casali 2014) and 2013 (Lira et al. 2013), in an environment previously dominated by chlorophyceae (Cunha and Calijuri 2011b). This seems to be supported by the present data, with rapid increases in the concentrations of both cyanobacteria (Fig. 6) and $\mathrm{Chl}$ (Fig. 5). If the present trends are maintained, worrying densities of cyanobacteria could be reached in the next years. Considering an exponential trend, concentrations above 395 cells $/ \mu \mathrm{L}$ would be expected in 2015 , reaching about 2164 cells $/ \mu \mathrm{L}$ in 2020.

For comparison, Bouvy et al. (1999) recorded a maximum of 374.5 cells $/ \mu \mathrm{L}$ during a cyanobacteria bloom at the Ingazeira reservoir in 1998. The temporal trend in cyanobacteria population growth observed at the Itupararanga reservoir therefore suggests the possibility of algal blooms in the near future. In São Paulo State, the reservoir with the highest recorded cyanobacteria population is the Billings reservoir, where the maximum abundance has varied between 151.92 and 2067.30 cells/ $\mu \mathrm{L}$ (CETESB 2005; 2006; 2007; 
2008; 2009; 2010; 2011; 2012; 2013; 2014; 2015). Large increases occurred during the course of only 3 years, despite the use of algicide in an attempt to control algal densities (CETESB 2012). In light of the situation at the Billings reservoir, the trends predicted here up to the year 2020 are plausible, considering the abundance of cyanobacteria predicted for 2015 and the value of 2164 cells $/ \mu \mathrm{L}$ predicted in 2020 . However, the values predicted for 2025 may be not realistic, when compared with data for other reservoirs in São Paulo State, because density-dependent factors are likely to have an interfering effect. At some point, densitydependent factors such as the availability and consumption of energy, as well as physical space, must act to restrict the exponential population growth of cyanobacteria, until a dynamic equilibrium is reached (Sakanoue 2007; Solbu et al. 2015). This is likely to occur before 2025, so abundances in the region of 11,849 cells $/ \mu \mathrm{L}$ may consequently not occur.

The evidence obtained here suggests that eutrophication and community adaptation are causing increases in Chl, associated with cyanobacteria growth. The tendency is for this process to continue, controlled primarily by nitrogen availability. However, the pattern of $\mathrm{Chl}$ and cyanobacteria growth could change following alterations in nitrogen inputs, as well as due to other factors that could limit phytoplankton and cyanobacteria growth in the future (Rangel et al. 2012).

The conditions observed in the Itupararanga reservoir suggest that the possibility of contamination of the water by toxins is likely to increase over time, given that the predominant organisms are recognized as potential toxin producers (Wood et al. 2014). The presence of saxitoxin (albeit still at safe levels) has already been detected in the Itupararanga reservoir, attributed to high levels of Cylindrospermopsis raciborskii (Woloszynska) Seenayya and Subba (Casali 2014).

\section{Conclusions}

Significantly different chlorophyll-a levels were found in the riverine and dam regions of the Itupararanga reservoir, as evidenced by ANOVA tests. The trophic state indexes showed frequent divergences due to the lack of a relationship between Chl and TP. This disagreement could be explained in terms of nitrogen limitation, based on the low levels of the nutrient (compared to levels reported elsewhere) and the relationship between $\mathrm{Chl}$ and $\mathrm{TN}$ evidenced in the models (Fig. 3, Table 2).

The adaptation of the phytoplankton community to a high trophic state has resulted in a community dominated by cyanobacteria, increasing the risk of water contamination by cyanotoxins. The use of the index for chlorophyll-a, weighted according to the nitrogen concentration, is strongly recommended for monitoring conditions in the Itupararanga reservoir and other similar tropical reservoirs. Indexes based on mean ratios of chlorophyll and phosphorus should be avoided in such cases.

Acknowledgments Financial support for this work was provided by FAPESP (Fundação de Apoio à Pesquisa do Estado de São Paulo, process numbers 2013/03494-4 and 2014/22581-8).

\section{References}

Beghelli, F. G. S., dos Santos, A. C. A., Urso-Guimarães, M. V., \& Calijuri, M. C. (2012). Relationship between space distribution of the benthic macroinvertebrates community and trophic state in a neotropical reservoir (Itupararanga, Brazil). Biota Neotropical, 12(4), 114-124.

Beghelli, F. G. S., Santos, A. C. A., Urso-Guimarães, M. V., \& Calijuri, M. A. (2014). Spatial and temporal heterogeneity in a subtropical reservoir and their effects over the benthic macroinvertebrate community. Acta Limnologica Brasiliensia, 26(3), 306-317.

Beu, S. E., Misato, M. T., \& Hahn, S. M. (2011). APA de Itupararanga. In S. E. Beu, A. C. A. dos Santos, \& S. Casali (Eds.), Biodiversidade na APA de Itupararanga (pp. 33-56). São Paulo: Grafilar.

Bogardi, J. J., Dudgeon, D., Lawford, R., Flinkersbusch, E., Meyin, A., \& Pahl-Wostl, C. (2012). Water security for a planet under pressure: interconnected challenges of a changing world call for sustainable solutions. Current Opinion in Environmental Sustainability, 4(1), 35-43.

Bouvy, M., Molica, R., Oliveira, S., Marinho, M., \& Beker, B. (1999). Dynamics of a toxic cyanobacterial bloom (Cylindrospermopsis raciborskii) in a shallow reservoir in the semi-arid region of northeast Brazil. Aquatic Microbial Ecology, 20, 285-297.

Burnham, K. P., Anderson, D. R., \& Huyvaert, K. P. (2011). AIC model selection and multimodel inference in behavioral ecology: some background, observations, and comparisons. Behavioral Ecology and Sociobiology, 65, 23-35.

Buzelli, G.M., Cunha-Santino, M.B. (2013). Análise e diagnóstico da qualidade da água e estado trófico do reservatório de Barra Bonita, SP. Revista Ambiente \& Água - An Interdisciplinary Journal of Applied Science, 8(1).

Carlson, R. E. (1977). A trophic state index for lakes. Limnology and Oceanography, 22(2), 361-369. 
Carneiro, F. M., Nabout, J. C., Vieira, L. C. G., Roland, F., \& Bini, L. M. (2014). Determinants of chlorophyll-a concentration in tropical reservoirs. Hydrobiologia, 740, 89-99.

Carpenter, S. R. (2003). Regime shifts in lake ecosystems. In O. Kinne (Ed.), Excellence in ecology. Germany: International Ecology Institute Oldendorf.

Casali, S.P. (2014). A comunidade fitoplanctônica no reservatório de Itupararanga (Bacia do Rio Sorocaba, SP). PhD thesis, Escola de Engenharia de São Carlos, USP, São Carlos, SP. http://www.teses.usp.br/teses/disponiveis/18/18138/tde25092014-152955/pt-br.php. Accessed 17 Mar 2015.

CETESB - Companhia Ambiental do Estado de São Paulo (2001). Qualidade das águas superficiais no estado de São Paulo. 2000. http://www.cetesb.sp.gov.br/agua/aguas-superficiais/ 35-publicacoes-/-relatorios. Accessed 17 Mar 2015.

CETESB - Companhia Ambiental do Estado de São Paulo (2002). Qualidade das águas superficiais no estado de São Paulo. 2001. http://www.cetesb.sp.gov.br/agua/aguas-superficiais/ 35-publicacoes-/-relatórios. Accessed 17 Mar 2015.

CETESB - Companhia Ambiental do Estado de São Paulo (2003). Qualidade das águas superficiais no estado de São Paulo. 2002. http://www.cetesb.sp.gov.br/agua/aguas-superficiais/ 35-publicacoes-/-relatórios. Accessed 17 Mar 2015.

CETESB - Companhia Ambiental do Estado de São Paulo (2004). Qualidade das águas superficiais no estado de São Paulo. 2003. http://www.cetesb.sp.gov.br/agua/aguas-superficiais/ 35-publicacoes-/-relatórios. Accessed 17 Mar 2015.

CETESB - Companhia Ambiental do Estado de São Paulo (2005). Qualidade das águas superficiais no estado de São Paulo. 2004. http://www.cetesb.sp.gov.br/agua/aguas-superficiais/ 35-publicacoes-/-relatórios. Accessed 17 Mar 2015.

CETESB - Companhia Ambiental do Estado de São Paulo (2006). Qualidade das águas superficiais no estado de São Paulo. 2005. http://www.cetesb.sp.gov.br/agua/aguas-superficiais/ 35-publicacoes-/-relatórios. Accessed 17 Mar 2015.

CETESB - Companhia Ambiental do Estado de São Paulo (2007). Qualidade das águas superficiais no estado de São Paulo. 2006. http://www.cetesb.sp.gov.br/agua/aguas-superficiais/ 35-publicacoes-/-relatórios. Accessed 17 Mar 2015.

CETESB - Companhia Ambiental do Estado de São Paulo (2008). Qualidade das águas superficiais no estado de São Paulo. 2007. http://www.cetesb.sp.gov.br/agua/aguas-superficiais/ 35-publicacoes-/-relatórios. Accessed 17 Mar 2015.

CETESB - Companhia Ambiental do Estado de São Paulo (2009). Qualidade das águas superficiais no estado de São Paulo. 2008. http://www.cetesb.sp.gov.br/agua/aguas-superficiais/ 35-publicacoes-/-relatórios. Accessed 17 Mar 2015.

CETESB - Companhia Ambiental do Estado de São Paulo (2010). Qualidade das águas superficiais no estado de São Paulo. 2009. http://www.cetesb.sp.gov.br/agua/aguas-superficiais/ 35-publicacoes-/-relatórios. Accessed 17 Mar 2015.

CETESB - Companhia Ambiental do Estado de São Paulo (2011). Qualidade das águas superficiais no estado de São Paulo. 2010. http://www.cetesb.sp.gov.br/agua/aguas-superficiais/ 35-publicacoes-/-relatórios. Accessed 17 Mar 2015.

CETESB - Companhia Ambiental do Estado de São Paulo (2012). Qualidade das águas superficiais no estado de São Paulo. 2011. http://www.cetesb.sp.gov.br/agua/aguas-superficiais/ 35-publicacoes-/-relatórios. Accessed 17 Mar 2015.

CETESB - Companhia Ambiental do Estado de São Paulo (2013). Qualidade das águas superficiais no estado de São Paulo.
2012. http://www.cetesb.sp.gov.br/agua/aguas-superficiais/ 35-publicacoes-/-relatórios. Accessed 17 Mar 2015.

CETESB - Companhia Ambiental do Estado de São Paulo (2014). Qualidade das águas superficiais no estado de São Paulo. 2013. http://www.cetesb.sp.gov.br/agua/aguas-superficiais/ 35-publicacoes-/-relatórios. Accessed 17 Sept 2015.

CETESB - Companhia Ambiental do Estado de São Paulo (2015). Qualidade das águas superficiais no estado de São Paulo. 2014. http://www.cetesb.sp.gov.br/agua/aguas-superficiais/ 35-publicacoes-/-relatórios. Accessed 17 Sept 2015.

Chaves, F. Í. B., Lima, P. F., Leitão, R. C., Paulino, W. D., \& Santaella, S. T. (2013). Influence of rainfall on the trophic status of a Brazilian semiarid reservoir. Acta Scientiarum. Biological Sciences. doi:10.4025/actascibiolsci.v35i4.18261.

CONAMA - Conselho Nacional do Meio Ambiente (2012). Resoluções do Conama: resoluções vigentes publicadas entre Setembro de 1984 e Janeiro de 2012. Brasília: Ministério do Meio Ambiente

Cunha, A. C. (2013). Revisão descritiva sobre qualidade da água, parâmetros e modelagem de ecossistemas aquáticos tropicais. Biota Amazônia, 3(1), 124-143.

Cunha, D. G. F., \& Calijuri, M. C. (2011a). Limiting factors for phytoplankton growth in subtropical reservoirs: the effect of light and nutrient availability in different longitudinal compartments. Land and Reservoir Management. doi:10.1080/ 07438141.2011.574974.

Cunha, D. G. F., \& Calijuri, M. C. (2011b). Seasonal variation of phytoplankton functional groups in the arms of a tropical reservoir with multiple uses (SP, Brazil). Acta Botânica Brasílica, 25(4), 822-831.

Cunha, D. G. F., Calijuri, M. C., \& Lamparelli, M. C. (2013). A trophic state index for tropical/subtropical reservoirs $\left(\mathrm{TSI}_{\mathrm{tsr}}\right)$. Ecological Engineering, 60, 126-134.

Dzialowski, A. R., Wang, S. H., Lim, N. C., Spotts, W. W., \& Huggins, D. G. (2005). Nutrient limitation of phytoplankton growth in central plains reservoirs, USA. Journal of Plankton Research, 27, 587-595.

Frascareli, D., Beghelli, F. G. S., Cardoso-Silva, S., \& MoschiniCarlos, V. (2015). Heterogeneidade espacial e temporal de variáveis limnológicas no reservatório de Itupararanga associadas com o uso do solo na Bacia do Alto SorocabaSP. Revista Ambiente \& Água, 10(4), 770-781.

Freedman, J. A., Curry, R. A., \& Munkittrick, K. R. (2012). Stable isotope analysis reveals anthropogenic effects on fish assemblages in a temperate reservoir: anthropogenic effects on fish assemblages. River Research and Applications, 28(10), 1804-1819.

Heath, S. K., \& Plater, A. J. (2010). Records of pan (floodplain wetland) sedimentation as an approach for post-hoc investigation of the hydrological impacts of dam impoundment: the Pongolo river, KwaZulu-Natal. Water Research, 44(14), 4226-4240.

Huszar, V. L. M., Caraco, N. F., Roland, F., \& Cole, J. (2006). Nutrient-chlorophyll relationships in tropical-subtropical lakes: do temperate models fit? Biogeochemistry, 7, 239250. doi:10.1007/s10533-006-9007-9.

Jordan, P., Melland, A. R., Mellander, P. E., Shortle, G., \& Wall, D. (2012). The seasonality of phosphorus transfers from land to water: implications for trophic impacts and policy evaluation. Science of the Total Environment, 434, 101-109. 
Karmakar, S., Haque, S. M. S., Hossain, M. M., \& Shafiq, M. (2011). Water quality of Kaptai reservoir in Chittagong Hill Tracts of Bangladesh. Journal of Forestry Research, 22(1), 87-92.

Katsiapi, M., Mazaris, A. D., Charalampous, E., \& MoustakaGouni, M. (2012). Watershed land use types as drivers of freshwater phytoplankton structure. Hydrobiologia. doi:10. 1007/s10750-012-1095-Z.

Kolzau, S., Wiedner, C., Rücker, J., Köhler, J., Köhler, A. Dolman, A.M. (2014). Seasonal patterns of nitrogen and phosphorus limitation in four German lakes and the predictability of limitation status from ambient nutrient concentrations. PLOS ONE, 9(4).

Lamparelli, M.C. (2004). Graus de trofia em corpos d'água do estado de São Paul. (Ph.D. thesis). São Paulo: USP.

Lira, V. S., Beghelli, F. G. S., Carvalho, M. M., Machado, F. H., Manfredini, F. N., Silva, J. P., et al. (2013). Macroinvertebrados bentônicos e cianobactérias como bioindicadores de qualidade de água: Estudo de caso no Reservatório de Itupararanga, bacia do Alto Sorocaba-SP. In A. I. Ribeiro (Ed.), Memórias do workshop de integração de saberes ambientais (pp. 83-87). Sorocaba: UNESP.

Liu, Y., Chen, W., Li, D., Huang, Z., Shen, Y., \& Liu, Y. (2011). Cyanobacteria-/cyanotoxin-contaminations and eutrophication status before Wuxi drinking water crisis in Lake Taihu, China. Journal of Environmental Sciences, 23(4), 575-581.

Logan, M. (2010). Biostatistical design and analysis using $R$ : $a$ practical guide. Wiley Blackwell: West Sussex.

Loiselle, S. A., Cózar, A., Dattilo, A., Bracchini, L., \& Gálvez, J. A. (2007). Light limitations to algal growth in tropical ecosystems. Freshwater Biology. doi:10.1111/j.1365-2427. 2006.01693.x.

Malheiros, C. H., Hardoim, E. L., de Lima, Z. M., \& Amorim, R. S. S. (2012). Quality of water of a dam located in an agricultural area (Campo Verde, MT, Brazil). Ambiente \& Água-An Interdisciplinary Journal of Applied Science, 7(2), 245-262.

Pedrazzi, F. J. M., Conceição, F. T., Sardinha, D. S., MoschiniCarlos, V., \& Pompêo, M. (2013). Spatial and temporal quality of water in the Itupararanga Reservoir, Alto Sorocaba Basin (SP), Brazil. Journal of Water Resource and Protection, 5(1), 64-71.

Pereira, P. S., Veiga, B. V., \& Dziedzic, M. (2013). Avaliação da influência do fósforo e do nitrogênio no processo de eutrofização de grandes reservatórios. Estudo de caso: usina hidrelétrica Foz do Areia. RBRH - Revista Brasileira de Recursos Hídricos, 18(1), 43-52.

Petrucio, M. M., Barbosa, F. A. R., \& Furtado, A. L. S. (2006). Bacterioplankton and phytoplankton production in seven lakes in the Middle Rio Doce basin, southeast Brazil. Limnologica, 36, 192-203.

Pretty, J. N., Manson, C. F., Nedwell, D. B., Hine, R. E., Leaf, F., \& Dils, R. (2003). Environmental costs of freshwater eutrophication in England and Wales. Environmental Science \& Technology, 37(2), 201-208.

R Core Team. (2015). R: a language and environment for statistical computing. Vienna: R Foundation for Statistical Computing. Available at: https://www.R-project.org/.

Rangel, L. M., Silva, L. H. S., Rosa, P., Roland, F., \& Huszar, V. L. M. (2012). Phytoplankton biomass is mainly controlled by hydrology and phosphorus concentrations in tropical hydroelectric reservoirs. Hydrobiologia, 693(1), 13-28.
Rosa, A.H., Silva, A.M.J., Melo, C.A., Moschini-Carlos, V., Guandique, M.E.G., Fraceto, L.F. et al. (2015). Diagnóstico ambiental e avaliação de uso e ocupação do solo visando a sustentabilidadede da Represa de Itupararanga, importante área da bacia do Médio Tietê. In: Pompêo, M., MoschiniCarlos, V., Nishimura, P.Y.,

Sakanoue, S. (2007). Extended logistic model for growth of single-species populations. Ecological Modelling. doi:10. 1016/j.ecolmodel.2007.02.013.

Salas, H. J., \& Martino, P. (1991). A simplified phosphorus trophic state model for warm-water tropical lakes. Water Research, 25(3), 341-350.

Salles, M. H. D., Conceição, F. T., Angelucci, V. A., Sia, R., Pedrazzi, F. J. M., Carra, T. A., et al. (2008). Avaliação simplificada de impactos ambientais na Bacia do Alto Sorocaba (SP). Revista de Estudos Ambientais, 10(1), 6-20.

São Paulo (2015). Diário oficial do Estado de São Paulo: Diários JusBrasil, July 15 2015, p. 3.

Saurí, D. (2013). Water conservation: theory and evidence in urban areas of the developed world. Annual Review of Environment and Resources, 38, 227-248.

Silvino, R. F., \& Barbosa, F. A. R. (2015). Eutrophication potential of lakes: an integrated analysis of trophic state, morphometry, land occupation, and land use. Brazilian Journal of Biology, 75(3), 607-615.

Sirigate, P., Stadler, C.C., Oroski, F.I. \& Kovaleski, J.L. (2005). Gestão da qualidade ambiental da água de mananciais de abastecimento público como estratégia de redução de custos. In: XXV Encontro Nacional de Engenharia de Produção, Porto Alegre, RS, Brazil. Oct./2005.

Smittenberg, R. H., Pancost, R. D., Hopmans, E. C., Paetzel, M., \& Sinninghe Damsté, J. S. (2004). A 400-year record of environmental change in an euxinic fjord as revealed by the sedimentary biomarker record. Palaeogeography, Palaeoclimatology, Palaeoecology, 202(3-4), 331-351.

Soares, M. C. S., Huszar, V. L. M., Miranda, M. N., Mello, M. M., Roland, F., \& Lürling, M. (2013). Hydrobiologia, 717(1), 1-12.

Solbu, E. B., Engen, S., \& Diserud, O. H. (2015). Guidelines when estimating temporal changes in density dependent populations. Ecological Modelling. doi:10.1016/j.ecolmodel.2015.06.037.

Taniwaki, R. H., Rosa, A. H., Lima, R., Maruyama, C. R., Secchin, L. R., Calijuri, M. C., et al. (2013). A influência do uso e ocupação do solo na qualidade e genotoxicidade da água no reservatório de Itupararanga, São Paulo, Brasil. Interciencia, 38(3), 164-170.

Torres, G. S., Silva, L. H. S., Rangel, L. M., Attayde, J. L., \& Huszar, V. L. M. (2016). Cyanobacteria are controlled by omnivorous filter-feeding fish (Nile tilapia) in a tropical eutrophic reservoir. Hydrobiologia. doi:10.1007/s10750-015-2406-y.

Tundisi, J. G. (2008). Recursos hídricos no futuro: problemas e soluções. Revista Estudos Avançados, 22(63), 7-16.

Tundisi, J. G., \& Matsumura Tundisi, T. (2008). Limnologia. São Paulo: Oficina de Textos.

UN - United Nations (2014). Un objetivo global para el agua post2015: Síntesis de las principales conclusiones y recomendaciones de ONU-Agua. http://www.un.org/spanish/ waterforlifedecade/pdf/findings_and_recommendations post2015 goal_water_spa.pdf. Accessed 18 Mar 2015.

Valente, J. P. S., Padilha, P. M., \& Silva, A. M. M. (1997). Oxigênio dissolvido (OD), demanda bioquímica de oxigênio (DBO) e demanda química de oxigênio (DQO) 
como parâmetros de poluição no ribeirão Lavapés/Botucatu SP. Ecletica Quimica, 22, 49-66.

Wood, S. A., Pochon, X., Luttringer-Plu, L., Vant, B. N., \& Hamilton, D. P. (2014). Recent invader or indicator of environmental change? A phylogenetic and ecological study of Cylindrospermopsis raciborskii in New Zealand. Harmful Algae, 39, 64-74.

Ye, C., Shen, Z. M., Zhang, T., Fan, M. H., Lei, Y. M., \& Zhang, J. D. (2011). Long-term joint effect of nutrients and temperature increase on algal growth in Lake Taihu,
China. Journal of Environmental Sciences. doi:10.1016/ S1001-0742(10)60396-8.

Zan, F., Huo, S., Xi, B., Zhu, C., Liao, H., Zhang, J., et al. (2012). A 100-year sedimentary record of natural and anthropogenic impacts on a shallow eutrophic lake, Lake Chaohu, China. Journal of Environmental Monitoring, 14(3), 804-816.

Zurr, A. F., Ieno, E. N., Walker, N. J., Saveliev, A. A., \& Smith, G. M. (2009). Mixed effects models and extensions in ecology with $R$. New York: Springer. 